Proceedings of the Seminar on the Social and Economic Effects. of Earthquake Prediction, 12 October, 1977.

\title{
THE POLITICAL AND LEGAL EFFECTS
}

\author{
Sir John Marshall*
}

I was born in wellington and have lived most of my life here, so I have been aware for most of my life that I was living in the vicinity of an earthquake fault line.

For about thirty years I worked in Parliament Buildings which succeeding Engineers in the Ministry of Works have consistently said is one of the worst earthquake risks in Wellington. I now have a room in the Hunter Building.

Wellington citizens have learned to live with this risk. When a noticeable shake occurs they may sometimes slide under the table or stand in a doorway. They know that major earthquakes have occurred here in the past. They accept that there is a probability that major earthquakes will occur in the future and they go about their common round and daily tasks without turning a hair.

But in both the political and legal areas about which I have been asked to speak this basic knowledge and this undisputed long term prediction has led to some sensible legal provisions and some political awareness of the need to provide safeguards in the event of a major earthquake.

We are now in this seminar and, as a result of continuing scientific research, being asked to contemplate a situation where seismologists may be able at some time in the not too distant future, to predict the place, the size and the time of earthquakes. While this cannot yet be done with precision or certainty, the research being undertaken indicates that we should be thinking of the consequences of more accurate earthquake prediction in the future.

Dealing first and briefly with the legal consequences, I can say that in most respects our present law is already adequate to deal, as far as law can, with the earthquake problem.

The protection of people from injury is provided for (so far as the law can do so) by local body bylaws (See Municipal Corporations Act 1954 ss. $386(14) 387$ and 410, Counties Act 1956 and New Zealand Model By-laws) regulating and controlling the design, construction, alteration and repair of buildings in relation to their resistence to earthquake shock. If these by-laws are correctly interpreted and enforced buildings complying with the by-laws should withstand any credible earthquake without collapsing. There may of course be some damage to the internal fittings and contents, but the structure should survive intact. This confident attitude of engineers leads

\footnotetext{
* Lawyer, former Prime Minister.
}

to the assurance that the safest place to be in an earthquake is in a modern building constructed in compliance with the model by-laws. There may be some lingering doubt when engineers go on to say that the by-laws are under constant review and are being up-dated and amended in the light of earthquake experience here and overseas. There is, for example, a recent revision of the New Zealand Standard By-law No. 1900 issued in February 1976 which contains controversial provisions which have not yet been adopted by some local bodies.

Accurate earthquake prediction would not affect these legal provisions which are already based on the assumption that what would then be predicted would in fact occur at some time anyway. But one can say with some confidence that the by-laws would be more strictly enforced and more willingly complied with if accurate earthquake prediction does come. There might also be some pressure on the part of property owners for government or local authority assistance in strengthening older buildings which have not by then been either pulled down or altered to comply with the building by-laws.

The law relating to the protection of Iife and the maintenance or restoration of community services in the event of a major earthquake is also reasonably well covered in the civil defence legislation by the civil defence organisation. Again, it is based on the assumption that major earthquakes will occur but one can also say with some confidence that if accurate earthquake prediction does come the provisions of the Civil Defence Act 1962 and Regulations would be more strictly enforced and the co-operation of the public within the earthquake zone would be much more enthusiastic than it is at present.

The law relating to compensation for personal injury as a consequence of earthquake is also adequate. This is covered by the Accident Compensation legislation. Accurate earthquake prediction would, one hopes, lead people to take what precautions they could to anticipate and avoid injury. but at least if they were injured, their rights to compensation for injury are clear. The law relating to compensation for damage to property is also well established. The Earthquake and War Damage Act 1944 provides that any property which is insured to any amount under any contract of fire insurance made in New Zealand with an insurance company shall also be deemed to be insured to the same amount against earthquake damage. Additional insurance and insurance on property not insured with the fire insurance cover can be arranged with the Earthquake and War Damage Commission. The only nagging 
doubt about this insurance cover is whether the funds in the hands of the Commission would be sufficient to meet the claims in the event of a major earthquake in a large urban area, particularly if the earthquake were followed by large scale fires. This legislation is also based on the assumption that earthquakes will occur and so the accurate prediction of earthquakes is only likely to result in people making sure that they are adequately covered and possibly in insurance companies imposing a higher premium for the insurance of property within the predicted earthquake zone.

This brief review of the law shows that both, for the protection of life and property and for the compensation of injury to people and damage to property, the law is already reasonably adequate. There are, however, situations which might arise if, as a result of the precise and certain prediction of a major earthquake in a defined place at a fixed time, local or central government or other authorities, public or private, took action which resulted in loss being suffered by others. The evacuation of towns, the closing of premises, the cancellation of services could cause loss or damage to people or property. Loss or damage might also be caused if the prediction turned out to be a false alarm. As a general rule our law does not impose absolute liability for causing loss or damage, but if an element of negligence or reckless disregard for the rights of others could be proved, legal liability for damages might follow. This is an area of the law which would have to be carefully examined if earthquake prediation were to become precise and certain. It might be necessary to pass legislation to protect authorities acting in good faith and at the same time to protect individual citizens against arbitrary abuse of power.

This concept leads on to the consideration of the much more difficult political problems which would arise if earthquake prediction reached the stage where seismologists were prepared to forecast with sufficient confidence and definition to justify central or local government taking official notice and accepting responsibility for official intervention.

Clarence $\mathrm{R}$. Allen in his 1976 presidential address to the Seismological society of America said: "no prediction should be considered valid unless the time, magnitude and area of occurrence are specified in writing within sufficiently well defined limits so that the ultimate success or failure of the prediction can readily be judged".

If the phrase "well defined limits" means an earthquake on a certain day in a clearly defined place at a high magnitude, the political problems would be comparatively simple - the government would order the evacuation of the place for the duration of the danger period. We have not yet achieved that degree of accuracy. The less accurate the prediction, the more difficult are the political decisions.

At the present time there is no political problem because we are not faced with any serious prediction of the kind referred to by Professor Allen. So the most that the Government can say is that we live in a country where small earthquakes frequently occur and a major earthquake may occur. Standard procedures are established to cope with that situation if and when it arises, but no further action is justified beyond the up-dating of the legal requirements in the light of increasing knowledge and the maintaining of the civil defence organisation at as high a level of efficiency as a lethargic public will tolerate.

If, however, seismologists are able to predict a major earthquake in a defined area is likely to occur within five years, I do not think a government can do more than ensure that the normal precautions through the established agencies are ready to go into action if and when required. If the time span could be narrowed to a matter of months a government would still be unjustified, in my view, in closing off the defined area although it would certainly have a responsibility to warn the public of the risk so that those who wished to leave the area could do so and all could take such other precautions as they might be advised to take and the authorities would ensure that the emergency services were in readiness.

But in addition to the problems of a prediction with a comparatively long time span gradually getting shorter there would be the political problems arising from the vague prediction and the prediction of doubtful or questionable authority. Should a government allow predictions which were vague or uncertain to be publicly announced? Should a government allow unqualified persons or persons without adequate qualifications to make public predictions? Should a government provide legislation to require predictions of earthquakes to be made only by official seismologists? Should it require the public announcement of such predictions to be made only by the responsible Minister?

I am inclined to think that it would be unwise to try to restrict the forecasting of earthquakes. Unqualified forecasters would carry light weight and qualified seismologists would be not only careful of their reputation but aware of their responsibilities to avoid panic and undue alarm. But before a government would be justified in taking action on an earthquake prediction it would be entitled to seek and act on the recommendations of its scientific advisers.

Further political problems arise where predictions turn out to be false alarms. Too many false alarms would undermine the credibility of the forecasts and shake the confidence and reduce the co-operation of the public.

On the other hand a government which failed to give public warning of a predicted major earthquake which did in fact occur would also carry a heavy responsibility and would undoubtedly be strongly criticised. Its term of office would be brief.

If the research now going on round the world leads, as many believe it will, to steadily increasing accuracy in the forecasting of earthquakes, Governments and Ministers will have to respond and accommodate themselves 
to the new situation. They will be entitled to rely on expert and official scientific advice but they will have to accept

responsibility for their decisions made on the basis of that advice. They will have to judge whether the advice or prediction is sufficiently sound and reliable to run the risk of alarming the public and disrupting community life in the area concerned.

They will have to weight up the possibility of false alarms undermining the confidence of the public as against withholding the warning and consequent protective measures until it was too late.

By and large I would favour an open policy in which the government would give the facts and assessments in a balanced and restrained way. This developing situation adds a new dimension to political responsibility.

\section{DISCUSSION}

Sir John commented that it was a difficult problem to know where it was safest for people to be in an earthquake, and what to do about schools or hospitals, for example. Clearly there would be a need for in depth studies following the prediction to visualise the effect of the earthquake so that government could make sensible decisions. Such studies should be available for public scrutiny.

Professor Roberts foresaw the time when the D.S.I.R. would approach the government for funds to initiate a detailed investigation into possible precursory phenomena in a particular area, and he asked Sir John whether he (if he was the Minister) would support such a proposition, and whether he would feel a responsibility to take it further both in government and with the public.

Sir John thought that the first prediction would involve a lead time of about 10 years and that there would therefore be time for government to prepare for the event and to carry out the necessary studies. However he acknowledged that governments tend to be concerned with the more urgent problems and that there might be a temptation to "put it off until next year". Sir John thought that there might be a lack of awareness of the problems associated with earthquake prediction in government and that it was important to address this problem now. 